UDC 930.22:003.074

061.75:003.074

Иван Балта

Свеучилиште у Осијеку

Оригиналан научни рад

Филозофски факултет

примљено: 1. јун 2012

Одсјек студија повијести

ibalta@ffos.hr

\title{
О ПИТАЫИМА ЛАТИНСКИХ КРАТИЦА НА ДИПЛОМАТИЧКИМ ПОВЕЉАМА
}

Сажетак: Кратице, интерпункције, сигле, те друге врсте кратица и бројевним знацима биле суставни део и старовековних а посебно средњовековних повеља. Како је израда материјала за писање била веома скупоцена, посебно коже (пергамене), прибегавало се скраћивању речи у тексту како би се на мањем простору могло написати што више текста. Сложеност проблематике јест да је свака канцеларија и регија те врста латинског писма (од каролине, беневентане, куријале до готице и хуманистике) имала свој систем скраћивања слова. Начин дешифровања појединих скраћеница у повељама јест на граници науке и уметности, а у којем су неки ауторитети имали своје својствене ставове и решења. Дешифровање и ишчитавање латинских рукописа је дипломатици и палеографији дала врло важно место у помоћним историјским наукама, а на чему се заснива једно од темељних делова развоја историјске науке уопште.

Кључне речи: краћенице, дипломатика, средњовековне повеље, латинске кратице

Појаву писања краћених латинских речи условљавала је штедња простора и материјала на којему се писало. Кратице су давале повољније предности за писара али и стварале тешкоће, које су временом постајале све теже и загонетније. ${ }^{1}$

У дипломатици и палеографији средњовековног латинитета посвећује се посебна пажња студију средњовековних кратица, а посебно студиј о кратицама у рукописима и њезино дешифровање. Но и даље су бројне кратице извесне епохе и одређене зоне специфичних облика и система остале неистражене и комплексне. Познавање специфичности кратица омогућавао је одређивање времена постања рукописа те земље у којој је рукопис настао, али су и даље кратице често задавале муке научницима античког и средњовековног латинитета, у њезином правилном читању и дешифровању. У почетку су кратице Римљани називали -notae-, а касније -sigla-, а за њих су тешкоће стварале одгонетавање натписа у епиграфици а касније

${ }^{1}$ Ј. Стипишић, Помоћне повијесне знаности у теорији и пракси, Школска књига, Загреб 1985, 32-67.

В. Новак, Латинска палеографија, Научна књига, Београд 1980, 282-285. 
и у палеографији. У одгонетавању кратица дао је свој допринос Валерије Пробо (50100. пре н. е.), у трактату о -litterae singulares- чији је део -Notarum laterculi- објавио Момсен. $^{2}$

Средњовековни скриптори су из збирке -Notae iuris-, преузимали кратице за књижевна и црквено-профана дела, а збирке кратица носиле су разне наслове, углавном према библиотеци у којој су се налазиле.

Међу старим кратицама је рукопис из VIII. века -Notae Lugdunenses- (из Лејденске библиотеке). Потом -Notae ex codice reginae-, -Notae iuris a Magnone collectae- (крајем VIII. века према рукописима из V. и VI. века, који су посвећени Карлу Великом), -Notae Lindenbrogianae-, затим -Notae Vaticanae-, -Notae Papianae et Einsidlenses-, прозване по Папиасу и његовом -Glossarium- из 1053., а у којима има делова кратица В. Проба. ${ }^{3}$

Кратице су биле тако раширене да ни царске заповеди о забрани исписивања законских зборника -notae iuris-, нису имали много учинка. Стога је Римски Сенат 438. године у -Теодозијевом зборнику-донео одлуку како се не смеју објавити закони написани са -notae iuris-: Huic codici, qui faciendus a constitutionariis, notae iuris non adscribantur. (Ова књига, коју је направио constitutionariis, кратице се не смеју одузети.). Мали број кратица имао је кодекс Breviarium Alaricianum-, највећим делом рађен на основу -Codex Theodosianus-, a који је као и Јустинијан забрањивао кратице. ${ }^{4}$ Изидор Севиљски је о истој ствари писао у XII. поглављу дела -Origines- о -De notis vulgaribus- и -De notis iuridicis-, да су цареви наредили да се -notae iuris- избаце из правних кодекса.

Велика употреба кратица условљавала је потребу приручника, а међу којима је био -Modus legendi abbreviaturas in utroque iure-. Касније је настао и други приручник Герсона: Quaedam regule de modo titulandi seu apificandi pro novellis

\footnotetext{
${ }^{2}$ T. Момсен (Th. Mommsen), Notarum laterculi. Zahl - und Bruchzeichen, 22, Hermes, 1887, 596-614. M. Valerii Probi de litteris singularibus fragmentum, u Notarum laterculi antiqui: H. Keil, Grammatici Latini, IV, Leipzig 1864, 50-100.

У својим изводима из Верија Флака (Verrius Flaccus), које је у одломцима сачувао Павле Ђакон (Paulus Diaconus) каже ce: "Nota nunc significant signum, ut in pecoribus, tabulis, libris, litterae singulae aut binae” („Обратите пажњу на знак који сада значи, као у говедима, плочама, књигама, на само једном или па два писма")

R. Сагнат, (R. Cagnat), Cours d'epigraphie latine, Paris 1914, 309.

В. Новак, Латинска палеографија, Научна књига, Београд 1980, 281.

И. Баlta, Преглед помоћних повијесних знаности, Матица хрватска, Осијек 2000. (о палеографији), 41.

${ }^{3}$ Fr. Стефенс (Fr. Steffens), Lateinische Paläografphie, Trier 1909. (125 Tafeln in Lichtdruck mit gegenüberstehender Transcription nebst Erläuterungen und einer systematischen Darsteilung der Entwicklung der lateinischen Schrift), Taf. XXXV

${ }^{4}$ Eandem autem poenam falsitatis constituimus et adversus eos, qui in posterum leges nostras per siglorum obscuritates ausi fuerint conscribere. Omnia enim, id est, et nomina prudentium et titulos et librorum numeros per consequentias litterarum volumus, non per sigla manifestari; ita ut qui talem librum sibi praverit, in quo sigla posita sint in qualemcunque locum libri vel voluminis, sciat inutilis se esse codicis dominum. Neque enim licentiam aperimus ex tali codice in iudicium aliquid recitare, qui in quacunque sua parte siglorum habet malitias.
} 
scriptoribus copulate. Обраду кратица је урадио Валтер, ${ }^{5}$ шта показује колика се потреба осетила за једним систематским делом о кратицама, неопходним латинисту, палеографу и дипломатичару. Валтерово дело садржи 225 табела, подељених у 450 ступаца у којима су алфабетским редом нанизане кратице, а било је и 28 факсимила.

Кратице су подједнако узимане из кодекса и повеља са назнаком форме кратица и века коме су припадале, односно када су се први пут појавиле. До данас се велики број Валтерових хронолошких података изменио, као термин -ante quem non-. Поред слике кратица, Валтер је додао и слова која садрже кратице те њено разрешење, на пример: vbi q. - vbique - vbicunque -. Раит ${ }^{6}$ је саставио лексикон за потребе енглеских палеографско-дипломатичких стручњака у одгонетавању кратица.

Kaсант $^{7}$ је објавио практични речник кратица, углавном епиграфских кратица те увео нови термин -la brachygraphie- и палеографску терминологију за две основне групе кратица -контракцију- и -суспензију-.

Приручник кратица издао је Хулаковски, ${ }^{8}$ а потом Волта ${ }^{9}$ и Капели. ${ }^{10}$ Кратице је Капели класификовао у шест група: 1. Abbreviature per troncamento (суспензије), 2. A. per contrazione (контракųuје), 3. A. per segni abbreviativi con significato proprio, 4. A. per segni abbreviativi con significato relativo, 5. A. per lettere sovrapposte, и 6. A . per segni convenzionali.

У обради и кориштењу кратица допринос су дали Ватенбах (Wattenbach), Томпсон (Thompson), Рејсенс (Reusens), Паоли (Paoli), Пру (Prou) и Стефенс (Steffens), али су нове научне методе за проучавање кратица унели Траубе, ${ }^{11}$ Линдсај $^{12}$ и Скиапарели, ${ }^{13}$ који су унапредили систематизовање краћеница. Скиапарели је после испитивања разних врста кратица, објављених у Archivio storico italiano, ${ }^{14}$ дао научну синтезу класификације краћеничких система и у

\footnotetext{
${ }^{5}$ J. L. Валтер (J. L. Walther), Lexicon diplomaticum, abbreviationes syllabarum et vocum in diplomatibus et codicibus a saeculo VIII ad XVI usque occurentes exponens, iunctis alphabetis et scripturae speciminibus integris, Gottingae 1745, Ulm 1756.

${ }^{6}$ А. Раит (A. Wright), Court Hand Restored, or the Student's assistant in Reading Old Deeds, Charters, Records..., London 1776, 1912.

${ }^{7}$ A. Касант (A. Cassant), Dictionnaire des abréviations latines et françaises usitées dans les inscriptions lapidaires et metalliques, les manuscrits et les chartes du moyen age, Eveux 1846, Paris 1884.

${ }^{8}$ J. М. Хулаковски (J. M. Hulákovský), Abbreviaturae vocabulorum usistatae in scripturis praecipue latinis medii aevi, tum etiam slavicis et germanicis collectae, Pragae 1852, 1913.

${ }_{9}^{9}$ 3. Волта (Z. Volta), Delle abbreviature nella paleografia latina, Milano 1892.

${ }^{10}$ А. Капели (А. Cappelli), Lexicon abbreviaturarum. Dizionario di abbreviature latine ed italiane usate nelle carte e codici specialmente del medio-evo riprodotte con oltre 14000 segni incici, Milano 1899, 1912, 1929.

${ }^{11}$ L. Tpayбe, (L. Traube), Nomina sacra. Versuch einer Geschichte der christlichen Kürzung, München 1907, 15.

${ }^{12}$ W. М. Линдсај (W. M. Lindsay), Notae Latinae. An Account of Abbreviation in Latin MSS. of the Early Minuscule Period (c. 750-850), Cambridge 1915, 10-25.

${ }^{13}$ L. Скиапарели, (L. Schiaparelli), Avviamento allo studio delle abbreviature latine nel Medioevo, Firenze 1926, 97-98.

14 - Note paleografiche. Segni tachigrafici nelle notae iuris. Archivio Storico Italiano, LXXII, 2, (1914.), 241254, LXXIII, и, (1915.), 245-275.

- Note paleografiche. Le natae iurise e il sistema delle abbreviature latine medievali. Archivio Storico Italiano, LXXIII, I, (1915.), s. 275-322.
} 
антици и у средњем веку. Линдсај је посветио већи број студија проучавању кратица у -Notae Latinae-, те поделио све кратице у три главне групе: 1. Notae communes, 2. Nomina sacra, 3. Notae iuris, а Скиапарели ${ }^{15}$ је провео своју класификацију кратица: 1. Litterae singulares: publicae, familiares. 2. Notae iuris. 3. Nomina sacra. 4. Notae communes. 5. Notae Romanae, christianae, medii aevi. 6. Abbreviature per troncamento e per contraxione. Највише је пажње изазвала тзв. група Nomina sacra, на којима је Траубе истраживао натписе и кодексе старохришћанског и ранога средњег века.

У латинске преводе из грчких текстова Библије ушле су контракције у Nomina sacra, можда већ od IV. века, као: -DS- за Deus, -IHS- за Jesus, -XPS- за Christus, -SPS- за Spiritus, али и касније варијанте: -DHS- или -DMS- za dominus, према грчком -KS-, а -SCS- за sanctus, а између V. и VI. века налазе се кратице CLRS- за clericus, -DACS- за diaconus, -EPS- за episcopus, $P B R$ за presbiter, $-R E V S-$ за reverendissimus.

Од VI века употребљавају се контракције -NI- за nostri, за nostro, -NM- за nostrum-. Дакле, контракције из Nomina sacra произишле су из грчког језика и у најстаријим латинским библијским текстовима.

Стефенс је поделио кратице римске епохе према у пет начина краћења: суспензије, notae Tironianae, контракције, notae iuris и знакови за бројеве. Према Новаку ${ }^{16}$ главнину средњовековних кратица чине: notae iuris, nomina sacra, те notae Tironianane, али и већи број краћеничких знакова. Стефенс је средњовековне кратице поделио на оне у тзв. националним писмима и на оне у каролиншкој и готичкој минускули. ${ }^{17}$ Дакле, нема једнинственог става о груписању и подели врста средњовековних кратица.

Интерпункција као кратица са значењем делења граматичких и мисаоних делова реченица имала је дуг процес развитка, а која је започела као античка structura continua. Тако је тачка на основној линији обележавала зарез, subdistinctio, а ако је била постављена на средини између обе линије, онда је то distinctio media, данашња тачка-зарез или семиколон.

Средњовековни скрипторији нису имали јединствена правила, а шта су забележили Изидор Севиљски и Алкуин, на шта је Севиљски упозорио писаре и изразио наду се да ће се то поправити: Punctorum vero distinctiones vel subdistinctiones licet ornatum faciant pulcherrimum in sententiis, tamen usus illorum propter rusticitatem pene recessit a scriptoribus, sed sicut totius sapientiae decus... renovari incipit, ita et horum usus in manibus scribentium redintegrandus esse optime

\footnotetext{
- Note paleografiche. Intorno all'origine e ad alcuni caratteri delle scrittura e del sistema abbreviativo irlandese. Archivio Storico Italiano, LXXIV, 2, (1918.), 3-128.

${ }^{15}$ L. Скиапарели (L. Schiaparelli), Note paleografische. 3. Influenza della scrittura beneventana sulla gotica? Archivio storico italiano, s. VII, vol. XI, I, 12-19.

${ }^{16}$ В. Новак, Латинска палеографија, II. издање, Београд 1980, 293.

17 Фр. Стефенс, (Fr. Steffens), Lateinische Paläografphue, Trier 1909. (125 Tafeln in Lichtdruck mit gegenüberstehender Transcription nebst Erläuterungen und einer systematischen Darsteilung der Entwicklung der lateinischen Schrift)
} 
videtur. $^{18}$

Севиљски је у Origines $(1,19)$ упозорио на три знака за делење реченице: -

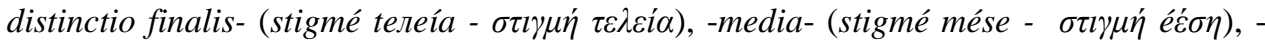

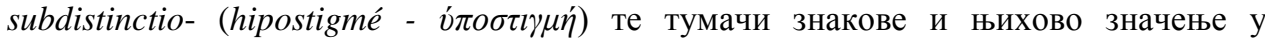
реченици: Уbi enim in initio pronuntiationis necdum plena pars sensus est, et tamen oportet respirare, fit comma, id est particula sensus, puncetusque ad imam litteram ponitur, et vocatur subdistinctio ab eo quod punctum subtus, id est ad imam litteram accipit. Ybi autem in sequentibus iam sententia sensum praestat, sed adhuc aliquid superest de sententiae plenitudine, fit colon, mediamque litteram puncto notamus, et mediam distinctionem vocamus, quia punctum ad mediam litteram ponimus. Ybi vero iam per gradus pronuntiando plenam sententiae clausulam facimus, fit periodus, punctumque ad caput litterae ponimus, et vocatur distinctio, id est disiunctio, quia integram separat sententiam. $^{19}$

У каролиншкој епоси латинског писма интерпункцијски систем није задовољавао потребе минускуле, посебно не у литургијским црквеним књигама одређеним за гласна читања, где је читаоц требао бити упозорен када треба гласом застати, попустити или подићи тон, а шта је узроковало појаву нових разноврсних интерпункцијских знакова. ${ }^{20}$

Писари средњовековних рукописа су требали познавати још једну скупину знакова, а за означивање шта би се морало изоставити додати, изменити и поправити у реченици. Севиљски у Origines $(1,21)$ дао је тим знаковима разна имена са њиховим функцијама у поглављу: De notus sententuarum, ${ }^{21}$ те забележио знакове: asteriscus, obelus, obelus superne adpunctus, limniscus, antigraphus cum puncto, asteriscus cum obelo, paragraplius, positura, cryphia, antisigma, antisigma cum puncto, diple, diple per stincon, diple per strigimene, diple bolismene, aversa, obolismene aversa cum obolo, diple superne obolata, diple recta et aversa obolata, ceraonium, crismon, phi et rho, anchora superior, anchora inferior, cronis, alogus.

Нису се сви знакови за кратице примењивали, па се на пример латински граматичар Капуанац (Thomas Capuanus, XIII. век) задовољавао са три основна интерпункцијска знака: Tres distinctiones considerantur existere, quarum prima comma, secunda colon, tertia periodos appellatur. Comma est punctum cum virgula superius ducta, scil. quum adhuc sensus suspensus remanet auditori. Colon est punctum planum cum animus auditoris necesse non habet aliud expectare, et tamen aliquid addi potest. Periodos est punctum cum virgula inferius ducta, quum animus auditoris amplius non expectat nec amplius querit discere intentionem proponentis. ${ }^{22}$

\footnotetext{
${ }^{18}$ Б. Бретолц (В. Bretholz), Leteinische Paläographie (Grundriss der Geschichtswissenschaft, Leipzig-Berlin, 1906. (1912, 1926.), 111, b. 3.

${ }^{19}$ В. Ватенбах (W. Wattenbach), Anleutung zur lateinischen Paläeographie, Leipzig 1886, 89.

${ }^{20}$ E. A. Lov (E. A. Lowe), The Beneventan Script, Oxford 1914, 227-279.

${ }^{21}$ Фр. Стефенс (Fr. Steffens), Lateinische Paläografphie, Trier 1909. (125 Tafeln un Lichtdruck mit gegenüberstehender Transcription nebst Erläuterungen und einer systematischen Darsteulung der Entwucklung der lateinischen Schrift), Tab. 33.

${ }^{22}$ E. A. Lov (E. A. Lowe), The Beneventan Script, Oxford 1914, 228-229, b. 4.
} 
Кратице су се разликовале не само по врстама латинског писма него и крајевима у којима су се развијали, дакако и по различитим временских епохама, а за поднебље источне обале Јадранског мора било је важно писмо беневентане, на пример:

Кратице латинског писма беневентане, свакако $m$ - линија представљала је специфичност, ${ }^{23}$ а кратице су настајале поступно па могу послужити као критериј за датирање, а изводиле су се на више начина краћења слова:

а) Суспензија косом линијом којој се сече једно слово

$$
\boldsymbol{E}=\text { eius } \boldsymbol{q}=\text { quod } \boldsymbol{F}=\text {-runt } \quad \boldsymbol{\psi}=\text {-rum }
$$

б) Апострофон који представља изостављено слово, а на десној страни је изнад последњег слова (-us, -s)

mun' $=$ munus $\quad$ huiu' $^{\prime}=$ huius

Знак као мала бројка 2 постављена изнад краћене речи може заменити водоравну линију као знак краћења

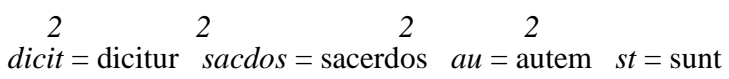

врло често се користила кратица налик на броју 3 као знак краћења

$$
\stackrel{3}{c u}=\operatorname{cum} \quad \stackrel{3}{\text { factu }}=\text { factum }
$$

в) Водоравна линија беше чести облик краћења беневентанског писма

$\overline{t p e}=$ tempore $\overline{g l} a=$ gloria $\overline{m i a}=$ misericordia popls $=$ populus $a m a=$ anima gra $=$ gratia

$\overline{q m}=$ quoniam $\overline{\text { mill }}=$ millesimo $\overline{\text { sic }}=$ sicut $\overline{d i x}=\operatorname{dixit}$

Водоравна линија као кратица изнад једносложних речи, на пример:

$\bar{s}=$ sunt $\bar{q}=$ quae $\bar{p}=$ prae $\bar{d}=$ de ${ }^{-} a=$ aut ${ }^{-} h=$ haec $\overline{-} e$ est $n=$ non

али и водоравна линија изнад неких консонаната:

$\bar{t}=$ ter $\quad t=\mathrm{ul}$, el (famto, angli) $\quad \bar{b}=$ bis, ber (nob, libtas) $\quad c=$ con, cen (ctra, innoctia)

\footnotetext{
${ }^{23}$ В. Новак (V. Novak), Scriptura Beneventana - с особитим обзиромна тип далматинске беневентане, Загреб 1920, 40.
} 
У ХІ веку појављују се нови облици краћења са суфиксом -tus и -tur, али и кратицама са водоравном линијом

$\overline{\text { nois }}=$ nominis $\quad \overline{\text { hois }}=$ hominis $\quad \overline{\text { ois }}=$ omnis

али и карактеристичне ознаке

' $=$ pri $\quad m^{\prime}=$ mihi $\quad g^{\prime}=$ igitur $\quad \stackrel{o}{g=\text { ergo } \quad t=\text { tri }}$

а у XII и XIII веку тзв. litterae suprascripturae постаје све већи:

$\begin{aligned} & \prime \\ & u=\text { uir }\end{aligned} \stackrel{o}{q}=$ quo $\quad \stackrel{o}{u}=$ uero

посебно изостављањем поједних слова ${ }^{-}$batus $=$beatus poitus $=$positus ipe $=$ipse Иако су кориштене многобројне кратице беневентански рукописи били су естетски дотерани и изједначени словима и дуљином текста „рro remedio animae“, како је написао Павле Ђакон: ${ }^{24}$

Scriptoris si forte uellis cognoscere nomen

Paulus diaconus uocitatur et ipose monachus

scruptor је био посве ангажован:

Tria digita scribunt $\quad$ (Три прста пишу

sed totum corpus laborat. али читаво тело ради.)

За Новака ${ }^{25}$ је у беневентани било специфично слово $c$, као кратко $c$ (као умањено капитално $c$ између две линије, основне и горње) и као дуго $c$ (које је настало из два слова $c c$, а која су налик на окренуту brojky 5. Видљиво је тзв. разбијено слово с у више примерака, као консекутивно, нпр. peccator, peccatore.

Скиапарели је најдубље ушао у суштину развитка минускуле у којима напомиње да су извесни франачки утицаји били јачи у прво време развитка беневентане те је нашао везу франачких утицаја на развитак беневентане на формирање слова $r$, али и везе између визиготике и предкаролиншке минускуле те ране беневентане. ${ }^{26}$

Латинско писмо каролина доминирало је Европом од VIII. до XII. века, у средњовековним изворима називана „littera francigena“27 или „minuta erecta“. Свако се слово пише за себе без претераних наглашавања и избегавају се сувишне украсне

\footnotetext{
${ }^{24}$ E. A. Lov (E. A. Lowe), The Beneventan Script, Oxford 1914, s. 331.

${ }^{25}$ В. Новак (V. Novak), Notae palaeographicae, chronologicae et historicae I. Antiquissimum fragmentum Sacramentarum Spalatensis, Вјесник Хрватског археолошког друштва, Н.C. XV, Загреб 1928, с. 189.

${ }^{26}$ L. Скиапарели (L. Schiaparelli), Influenze straniere nella scrittura Italiana dei secoli VIII e IX. Note paleografische. (Studi e testi. 47.), Roma 1927, 38-63.

${ }^{27}$ В. Новак (V. Novak), Латинска палеографија, Београд 1980, 182.
} 
линије. Лигатуре су углавном узимане из римске курзивне минускуле те делимично из унцијале, а најчешће беху: $c t, e t, n t, r s, s t$, но кратице су врло ретке, иако њихов број од ХІ. века бива све чешћи.

Углавном су кратице били знакови краћења за наставке -ur и -er, али и мали апострофи изнад последњег слова, на пример: pertubant' = pertubantur, hui' = huius, али се понекад користила водоравна линија за изостављено $-m$ или валовита линија изнад последњег вокала, на пример:

experimentu $=$ experimentum

Карактеристичан пример каролиншког минускулног рукописа из IX. века је Готшалков кодекс у Берну, ${ }^{28}$ у којем се спомиње име хрватског кнеза Трпимира, а у чијем тексту има поједних кратица.

Извадак из једног дела целокупног текста (Gotschhark codex) у транскрипцији и транслитерацији:

Quia scilicet ${ }^{29}$ quando semimortui homis intuetur ${ }^{30}$ imminere in $^{31}$ iam ...

Cum etiam corui milui uulteres et aquila e ${ }^{32}$ temporibus ...

Quod prorsus ego ipse per Gottescalcum ${ }^{33}$ filiolum meum de equo nostro probaui.

Cum enim Tripemirus rex Sclauorum ${ }^{34}$ iret contra gentem Grecorum ${ }^{35}$ et patricium eorum ...

Кратице су се још више користиле у каснијем периоду у тзв. средњовековним писмима каролино-готице, ако што се наводи на примеру повеље Кулина бана упућено Дубровачкој Републици 29. августа 1189. године (препис у Државном архиву у Дубровнику, а вероватни оригинал у Библиотеци Академије наука у Ст. Петербургу). Текст је двојезичан, написан на латинском језику и тзв. босанчицом или ћирилицом.

повеља Кулина бана из 1189. године

† In nomine patris et filii et spiritus ${ }^{36}$ sancti ${ }^{37}$ amen. ${ }^{38}$ Ego banus

Culinus Bosne ${ }^{39}$ iuro comiti Geruasio et omnibus ${ }^{40}$

\footnotetext{
${ }^{28}$ J. Стипишић, Помоћне повијесне знаности у теорији и пракси, Загреб 1972, 89-90. (Gotschalk codex, Biblioteca Bongarsiana, cod. 584., Богословска смотра, Загреб 1932.)

${ }^{29}$ Реч завршава лигатуром $e t$, која се у тексту често понавља.

${ }^{30}$ Понавља се лигатура et.

${ }^{31}$ Реч почиње са такозваном $и$ лопga, која се у тексту и даље понавља.

${ }^{32}$ Написан је дифтонг $a e$, али се налази и дифтонг написан $e$ (caudata) и на обично $e$ без икакве ознаке дифтонга.

${ }^{33}$ Почетно је слово написано у минускулом облику.

${ }^{34}$ Такође је почетно је слово написано у минускулом облику.

${ }^{35}$ Почетно је слово минускулно у тексту.

${ }^{36}$ Није написано spiritus, него кратица spi, иако кратицу треба читати spiritu као spiritus, јер се крајњи сугласник изиставља ако идућа реч почиње истим сугласником - spiritu(s) sancti -

${ }^{37}$ Уместо sancti, написана је кратица sci са водоравном линијом изнад кратице

${ }^{38}$ Уместо amen, написана је кратица ат са водоравном линијом изнад кратице
} 
Raguseis rectum amicum fore perpetuo ${ }^{41}$ et rectam uobiscum ${ }^{42}$ pacem manutenere ${ }^{43}$ et amicitiam ${ }^{44}$ ueram, et omnes $^{45}$ Raguseos per ${ }^{46}$ totam terram ${ }^{47}$ nostram ${ }^{48}$ ambulantes mercantes seu habitantes uel transeuntes recta fide et conscientia uera recipere $e^{49}$ absque ulla datione, nisi quis ${ }^{50}$ suam per uoluntatem ${ }^{51}$ mihi $^{52}$ donum dare uoluerit, et aput nos dum fuerint manutenere, et consilium eis preber $e^{53}$ nostre ${ }^{54}$ persone $^{55}$ $a d^{56}$ nostrum ${ }^{57}$ posse absque fraude et malo ingenio. Sic me deus ${ }^{58}$ adiuet $^{59}$ et hec sancta ${ }^{60}$ IIIor euangelia.

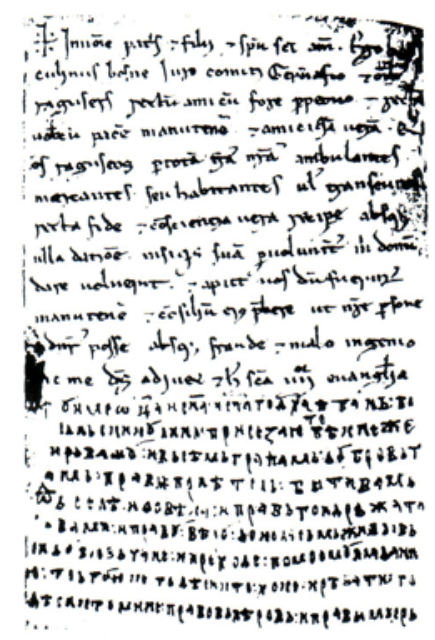

${ }^{39}$ Граматички би било исправно Bosnae, али је скраћено на Bosne

${ }^{40}$ Написана је уместо речи omnibus кратица omn са карактеристичним знаком кратице изнад кратице

${ }^{41}$ Уместо perpetuo написана је кратица за per, прецртани доњи дуктус слова $p$ и додан наставак реtuo

42 Уместо речи иobiscum написана је неуобичајена кратица иobm, с водоравном линијом изнад кратице

${ }^{43}$ Уместо речи таnutenere написана је кратице са изостављеним re а изнад $е$ стављена је водоравна линија

${ }^{44}$ Писар је употребио беневентанску лигатуру $t i$

${ }^{45}$ Уместо речи отпеs стављена је кратица os и водоравна линија изнад слова $o$

${ }^{46}$ Уместо per стављена је кратица, прецртани доњи дуктус слова $p$

${ }^{47}$ Уместо речи terram стављена је кратица tra са водравном цртом изнад кратице

${ }^{48}$ Уместо речи nostram стављена је кратица nra са водравном линијом изнад кратице

${ }^{49}$ Реч recipere замењена је кратицом гесіре у којем је слово $p$ прецртано у доњем дуктусу

${ }^{50}$ Кратица quis настала је прецртавањем оси слова $q$ (писар је ос продужио, заоблио и скренуо удесно те пресекао исту ос)

51 „uолuntatem“ “ је краћена без задњег слова „uolunt““, на тада уобичајен начин

${ }^{52}$ Кратица mihi, написана као $m$ (са косом линијом изнад слова $m$ )

${ }^{53}$ Реч prebere замењена је кратицом слова $p$ прецртано у доњем дуктусу и наставком bere

${ }^{54}$ Уместо речи nostre стављена је кратица пre са водравном линијом изнад кратице

${ }^{55}$ Реч persone замењена је кратицом слова $р$ прецртано у доњем дуктусу и наставком sone

${ }^{56}$ Вероватно пише $a d$, иако је исправа на том месту оштећена

${ }^{57}$ Уместо речи nostrum, написана је кратица $n r$ са горњом водоравном линијом

${ }^{58}$ Уместо речи deus, написана је кратица $d s$ изнад које је водоравна линија

${ }^{59}$ На крају речи adiu, налази се лигатура $e t$, што се чита adiuet

${ }^{60}$ Уместо речи sancta, написана је кратица sca изнад које је водоравна линија 
Вероватно ни у једном другом средњовековном писму није био развијен систем кратица као у готици, посебно специфичним у правним, филозофским, медицинским и теолошким рукописима. Кратице су биле веома сложене јер су се знакови краћења понекад стављали даље од уобичајеног места или изнад речи којима су припадали. Сложени и дијакритички знакови изнад слова $u$ који могли су бити изражени тачком или косом линијом, па је систем кратица био индивидуалан. Суспензије су се често састојале од првога слова у речима и изразима које су се често понављале, као: a. = actor, n.q.s. = nomine que supra. Готово је свака канцеларија за писање средњовековних јавних и приватних исправа имала свој систем кратица.

Карактеристичан пример књижне готице из 1405. године је „Historia Ragusii“ чији је аутор Iohannes de Conversio de Ravenna ${ }^{61}$ (налази се у Biblithèque Nationale, Paris MS latins. 6494.)

Historia Ragusii (Историја Дубровника) из 1405. године

\section{Historia Ragusii Iohannes de}

Ravenna

Silentii mei, vir

honorande, fort-

asse admirabun-

dus causam expectas

quam prodere ten-

tantem negocio-

rum $^{62}$ et curarum impetus auertit. Mul-

ta uero ${ }^{63}$ cum sint, que scribi uelit,

plura tamen ${ }^{64}$ calamum abducunt, quibus ${ }^{65}$

usque adeo infesus mihi ${ }^{66}$ sum, $u t^{67}$

haud facile dixerim quam ${ }^{68}$ primum

ingeram manum fortuna preterita ${ }^{69}$

nec ${ }^{70}$ mitior presens ${ }^{71}$ peregrinacio, infeli-

citas uite incommoditasque et rerum ${ }^{72}$

\footnotetext{
${ }^{61}$ Книевалд, Д. (Kniewald, D), Iohannes de Ravenna, дубровачки нотар 1384-1387., Глас Српске академије наука и уметности, књига 29, Београд 1957, 160.

${ }^{62}$ Реч negociorum замењено је кратицом пеgосіо и доданом кратицом у облику бројке 4, која замењује рум

${ }^{63}$ Кратица ио изнад које је водоравна линија замењује реч иего

${ }^{64}$ Кратица $t n$ изнад које је водоравна линија замењује реч tamen

${ }^{65}$ Кратица qb поред којег је зарез замењује реч quibus

${ }^{66}$ Реч mihi замењује слово $m$ изнад које је усправна линија

${ }^{67}$ Реч $u t$ треба само попунити празнину у тексту, иначе нема посебну сврху

${ }^{68}$ Реч quат замењује кратица $q$ изнад које је валовита линија

${ }^{69}$ Такође реч $t a$ треба попунити празнину у тексту, иначе нема посебну сврху

${ }^{70} n^{\prime}$ је кратица за реч пес

${ }^{71}$ Реч presens замењује кратица $p n s$ изнад $n$ је тачка

${ }^{72}$ Реч rerum замењено је кратицом rе и доданом кратицом у облику бројке 4, која замењује -rum
} 


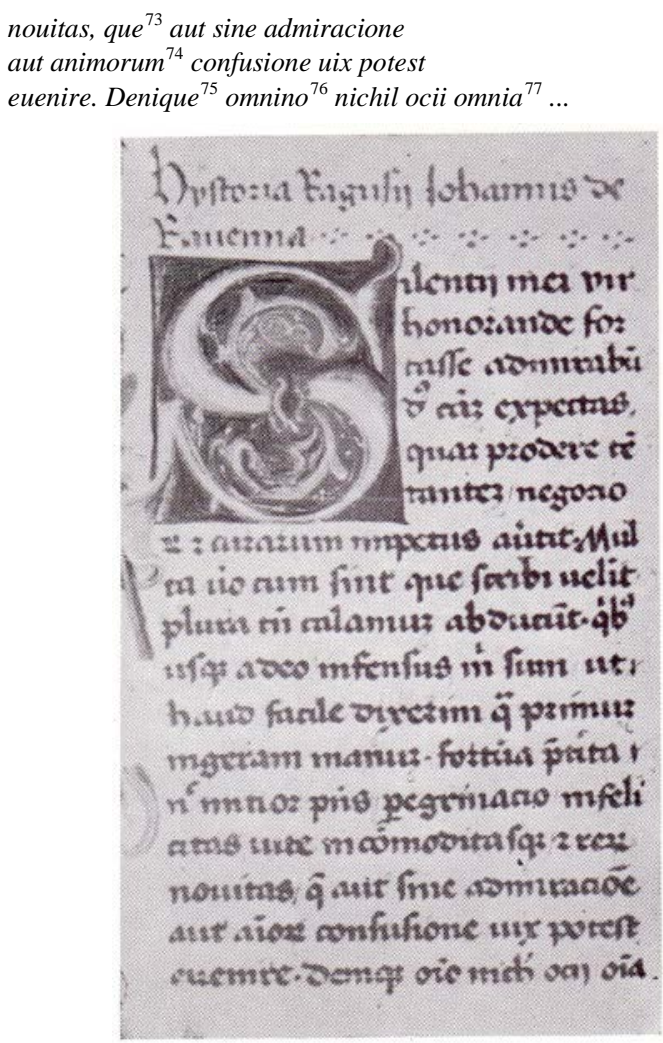

Готица се развијала као латинско писмо у специфичним условима отварања и развоја многобројних европских универзитета па све до афирмације Гутенбергових штампаних књига, углавном називана „scriptura gothica“, како је назива и Мабијон. Писање великог броја рукописа и кодекса изискивало је поделу рада у радионицама рукописа, а о чему је известио и Франческо Петрарка: „Sic aupud nos alii membranas radunt, alii libros scribunt, alii corrigunt, alii, ut vulgari verbo utar, illuminanat, alii ligant et superficiem comunt.“78

У „Scripturae insularis“ у полуунцијали и унцијали, употребљавала се од VI. века до краја средњег века у Ирској, а у Енглеској до норманске инвазије 1066. године.

\footnotetext{
${ }^{73}$ Кратица $q$ изнад које је водоравна линија замјењује ријеч que

${ }^{74}$ Реч animorum замењено је кратицом аіо са водоравном линијом изнад кратице и доданом кратицом у облику бројке 4, која замењује -rum

${ }^{75}$ Реч denique замењује кратица deniq:

${ }^{76}$ Кратица оіо с водоравном линијом изнад кратице означава реч отпіпо

${ }^{77}$ Кратица оіа с водоравном линијом изнад кратице означава реч отпіа

${ }^{78}$ Epistolae familiares XVIII, epistoлае, nr. 5.
} 
Систем кратица у тзв. острвским латинским писмима био је особит, а темељио се на систему из римскога доба, на notae iuris и пotae tironianae, задржане и после Јустијановог доба, посебно у правним документима.

autem con contra eius

Карактеристичне беху тиронске кратице:

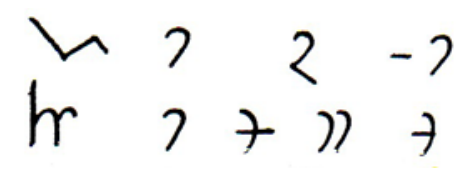

као и посебне ирске кратице:

enim esse est et vel

затим тиронске кратице:

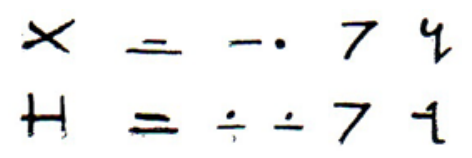

као и ирске кратице:

Бројевним знаком 7 означавао се наставак: -ut на пример: tant7 = tantum

Интересантне су кратице суспензије које су настале употребом апострофа:

$p^{\prime}=$ post,$c^{\prime}=$ cum, $t^{\prime}=$ tur, $m^{\prime}=$ mihi, $s^{\prime}=$ sed, $i g^{\prime}$ или $g^{\prime}=$ igitur

затим, истоветне кратице помоћу тачке:

$b \cdot=$-bus, $q \cdot=$-que

Посебно су запажене кратице које су се писале са две тачке:

$. b .=$ bene, $. i .=$ idest,

$. s .=$ sic aлebo sed, $q:=$ que, quicumq: = quicumque, $. n .=$ nec, $. d c .=$ dictum

Посебне кратице беху стављањем малих знакова изнад другог слова:

$\dot{n}=$ nunc,

$h^{\prime}=$ hunc, $\dot{s}=$ sicut aлebo sic 
Изнад краћене речи понекад се стављала водоравна линија:

$\overline{\text { un }}=$ unde, $\bar{c}=$ cum,

$\overline{\text { dic }}=$ dictum, $\bar{s}=$ sed, $\bar{b} n=$ bene, $\bar{n} o=$ nomen, $\bar{d} n=$ donec, $n s=$ nisi, qn = quando,

$\overline{u n}=$ unde, $\overline{e r}=$ ergo, $\overline{\text { dic }}=$ dictum

а ознака за изостављање -ее стављала се водоравна линија изнад слова:

$p, g, b, c, t, u, e, f$

на пример: trio $^{-}=$tertio, conutentur $=$convertentur

Употребом водоравне црте означавале су се контракције:

$\overline{h c}=$ hunc, $\overline{\text { quo }}=$ quando,

$\overline{c s}=$ cuius, $\overline{d n} r$ dicuntur, $\bar{d} r e=$ dicere, $\bar{d} n t=$ dicunt

Посебне или специјалне кратице биле су:

quis propter quos quas et reliqua

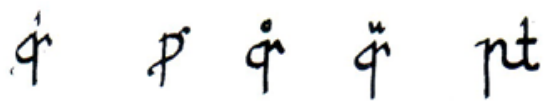

те кратице:

per quam, quia

p q

Био је то избор само мањег броја кратица из латинских повеља који се користио у комплексном кориштењу средњовековних кратица. 


\title{
THE ISSUES OF LATIN ABBREVIATIONS IN THE DIPLOMATICES DOCUMENTS
}

\begin{abstract}
Summary
The issues of Latin abbreviations in the diplomatic documents are a very complex problem in the diplomatic word processing and deciphering the historiography documents.

Abbreviations originated from Latin letters caused a favorable advantage for the scribe, but created difficulties for the reader, since they were complicated and questionable at the time. The Romans called the Latin abbreviations notae-or-sigla, using them just to save space and materials on which the letters were written. Increased use of abbreviations in medieval manuscripts emphasized a need for a manual in both the Code and Charter, specifying the form of abbreviations and centuries which they belonged to. Steffens divided the abbreviations of the Roman epoch according to the chronological development into the five ways of shortening: suspension, notes Tironianae, contraction, notes iuris, and signs for numbers, which were retained and added new shortcuts in the Middle Ages, especially in the territory of today's Pannonia and the Eastern Adriatic coast.

Punctuation, which was alike the abbreviations, had a long process of development, which began as an antique-scriptura continua, trying to clarify the meaning of putting points in various positions between the individual words.

Abbreviations differed not only by the type of Latin letters, but also by the territory in which they evolved, at different time periods. Abbreviations of Latin letters from the Beneventan East Adriatic coast were specific, were formed gradually, could be used as a criterion for dating, and were carried out with more ways of shortening the letters. Schiaparelli probably entered the deepest essence of the development of Latin minuscule in which he noted that the Frankish influences were much stronger in the first period of the development of the Beneventan East Adriatic coast. However, perhaps no other medieval script was developed better than a system of abbreviations in the Gothic style, especially in the legal, philosophical, medical and theological writings in Pannonia. Almost every office in which medieval public and private documents were written had its own system of abbreviations, which additionally complicated deciphering of complex abbreviations which had different impacts in the territory of Pannonia and the Eastern Adriatic coast.
\end{abstract}

Keywords: abbreviations, diplomacy, medieval charters, Latin abbreviations 